\title{
Correction to: Patients satisfaction with healthcare delivery in Ghana
}

Daniel Adjei Amporfro ${ }^{1}$, Michael Boahn², Shao Yingqi ${ }^{1}$, Therese Martin Cheteu Wabo ${ }^{3}$, Miaomiao Zhao ${ }^{4}$, Victorine Raissa Ngo Nkondjock ${ }^{3}$ and Qunhong $W^{1 *}$

\section{Correction to: BMC Health Serv Res 21, 722 (2021).} https://doi.org/10.1186/s12913-021-06717-5

Following publication of the original article [1], the order that the authors appeared in the author list was incorrect. The reason is that the authors mistakenly placed the corresponding author Qunhong $\mathrm{Wu}$ at first.

The author list has been updated above and the original article [1] has been corrected.

\author{
Author details \\ 'Department of Social Medicine, School of Health Management, Harbin \\ Medical University, Harbin, Heilongjiang, China. ${ }^{2}$ Department of \\ Epidemiology, Biostatistics and Disease Control, School of Public Health, \\ University for Development Studies, Tamale, Ghana. ${ }^{3}$ Department of Nutrition \\ and Food Hygiene, Harbin Medical University, Harbin, Heilongjiang, China. \\ ${ }^{4}$ Department of Health Management, School of Public Health, Nantong \\ University, Nantong, Jiangsu, China.
}

Published online: 25 August 2021

\section{Reference}

1. Amporfro DA, et al. Patients satisfaction with healthcare delivery in Ghana. BMC Health Serv Res. 2021;21:722.

The original article can be found online at https://doi.org/10.1186/s12913021-06717-5.

* Correspondence: wuqunhong@163.com

'Department of Social Medicine, School of Health Management, Harbin Medical University, Harbin, Heilongjiang, China

Full list of author information is available at the end of the article

(C) The Author(s). 2021 Open Access This article is licensed under a Creative Commons Attribution 4.0 International License, which permits use, sharing, adaptation, distribution and reproduction in any medium or format, as long as you give appropriate credit to the original author(s) and the source, provide a link to the Creative Commons licence, and indicate if changes were made. The images or other third party material in this article are included in the article's Creative Commons licence, unless indicated otherwise in a credit line to the material. If material is not included in the article's Creative Commons licence and your intended use is not permitted by statutory regulation or exceeds the permitted use, you will need to obtain permission directly from the copyright holder. To view a copy of this licence, visit http://creativecommons.org/licenses/by/4.0/. The Creative Commons Public Domain Dedication waiver (http://creativecommons.org/publicdomain/zero/1.0/) applies to the data made available in this article, unless otherwise stated in a credit line to the data. 